\title{
Verena Krebs, Medieval Ethiopian Kingship, Craft, and Diplomacy with Latin Europe, Springer Nature, Cham 2021, xvii+308 p., eBook, ISBN: 978-3-030-64934-0
}

\section{Samuel Rubenson*}

In her book on the exchange between medieval Ethiopia and Latin Europe, Verena Krebs has provided us with a crucial contribution to Ethiopian history, a contribution that radically challenges the traditional perspective on Ethiopia's medieval contacts with the Latin world. As stated in the introduction the book constitutes an attempt to answer the simple question of why generations of Ethiopian rulers in the fifteenth and early sixteenth century repeatedly sent diplomatic missions to the courts of Latin Europe despite the hardships involved and the often meagre outcomes. For each mission, as well as for the European missions sent in reply, Krebs analyzes in detail the wide range of sources in Gi' iz, Arabic, Latin, Catalan, French, German, Italian and Portugese. It is a fascinating story of bold enterprises, long, arduous journeys and patient waiting, a story of majestic reception as well as imprisonment and beheading, curiosity, misinterpretation and false hopes. By contrasting the sources, Krebs manages to present a history of an exciting cultural and political exchange in which the expectations and goals were quite different. Despite her emphasis on this difference, the exchange also reveals how Ethiopia was part of the same late medieval world as Portugal and Spain, and a world in which art and architecture, far distance trade and travel, and religiously legitimatized royal rule belonged together.

Against half a century of scholarship that has treated the Ethiopian missions to Latin Europe as expressions of interest by Ethiopian rulers in European technology to enhance its military efficiency, Krebs demonstrated convincingly that the missions were primarily about obtaining precious religious artefacts, such as relics and precious objects of religious art, including recruiting artisans who could embellish royal churches and monasteries. The purpose was not to gain military aid but to strengthen royal legitimacy and consolidate the Solomonic dynasty by providing evidence for its universal recognition. The missions should be seen in relation to the propagation of texts like the Kibre Negest and the Fitha Negest rather than concerning a conflict with Ethiopia's Muslim neighbors or Mamluk rule. As Krebs demonstrates the interest in a military alliance against the Muslim rulers of the Near East was primarily on the side of the Europeans.

\footnotetext{
* Samuel Rubenson, Centre for Theology and Religious Studies, Lund University, Box 192, SE-22100 Lund, Sweden, samuel.rubenson@ctr.lu.se.
} 
Krebs's study is yet another example of how Ethiopian history, as African history in general, has been examined from the perspective of European imagination, exploration and interests. A major reason, in addition to strong European ideas of supremacy, is of course the paucity of Ethiopian original sources. Although Krebs provides a plausible explanation for Ethiopian royal interests in Latin Europe and the Ethiopian missions, we know very little about what the Ethiopian elite knew about the people to whom the missions were sent and how they had obtained that knowledge. What did the kings and their ambassadors think and how did they interpret what they encountered? Unfortunately, we have to go to the early nineteenth century to find more numerous original Ethiopian sources. The letters of the early volumes of Acta Aethiopica, do, however, confirm many of Krebs's observations and conclusions in again having an emphasis on art and architecture rather than any military alliance.

As with any excellent scholarly work, Krebs's study not only challenges presuppositions and scholarly literature, but also raises several questions and thus contributes to generating new research. For this, the most important is perhaps the realization that Ethiopian society, at least as far as the elite goes, was much more similar to late medieval European society than orientalism has made us believe, and that Ethiopian rulers had the same interests and shared the same means in consolidating their rule as their European counterparts.

Krebs should finally also be credited with providing us with extensive footnotes that not only give reference to and lengthy quotations from the sources as well as to previous scholarship but also discusses several intriguing issues related to the history of art and architecture in Ethiopia. A useful glossary, an extensive bibliography, and a rich index are also provided. 


\section{Bonnie Efros, Isabel Moreira (eds.), The Oxford Handbook of the Merovingian World, Oxford University Press, New York 2020, 1166 p. ISBN: 9780190234188 (hardback), ISBN: 9780197510803 (epub)}

\section{Corina Cioltei-Hopârtean*}

A volume that took six years to see the light of day, the Oxford Handbook of the Merovingian World, published and coordinated by Bonnie Effros and Isabel Moreira offers all that a handbook promises: „a concise reference book covering a particular subject", pervading all aspects of it, namely the Merovingian world of the fifth to eighth centuries through all forty-six essays, written by contributors from prestigious universities and research centers in the United States of America and Europe, all of them being listed at the beginning of the volume.

After the Table of Contents, Acknowledgements, List of Abbreviations, List of Contributors and List of Maps, a well-documented and carefully thoughtout Introduction the reader is presented with the studies, organized into eight parts, reflecting the scope of each researcher The essays are all put together within the volume as to create a series of narratives whose aim is to "rebuild" the Merovingian world and thus pushing its story further than what historians, starting with Edward Gibbon's eighteenth-century view and up until the present, thought and made of it, namely a few pages in the history books. These narratives stretch from the Merovingian Historiography and the History of Archaeology (Part I) to studies aiming at Expressing the Identity of the Merovingians (Part II) which led to the rise of their Structures of Power (Part III), bringing Merovingian Gaul in a Wider Context (Part IV). The progress made by generations of Merovingians led to the memory of such, to traces of their particular Merovingian Written Culture (Part V), which are also explored in the volume, contributing most likely to the possibility of researching the Merovingian Landscapes (Part VI). This world was not an isolated one, it needed sustainability and as such developed Economies, Exchange, and Production (Part VII). The volume, wrestling with the topic from its "birth", ends with an emphasis upon how and what the Merovingians thought about the Supernatural and the Afterlife (Part VIII) and how they cared for that during their lifetime.

The contributors of Part I, Paul Fouracre, Agnés Graceffa and Bonnie Effros bring forward results into the impact of the Merovingians which contributed to the development of Gaul into Francia and became a key position within the geopolitical frame of the Middle Ages. These results

\footnotetext{
* Corina Cioltei-Hopârtean, Referent la Institutul de Cercetări Socio-Umane Sibiu, Bulevardul Victoriei 40, Sibiu, Romania, corinahopartean@yahoo.com.
} 
stem either from centuries-old historiography that needed to be revised or reinterpreted, as well as from results derived from archaeological excavations from recent years.

The essays attributed to Part II, signed by Magali Coumert, Wolfram Drews, Andrea Czermak, Guy Halsall and Émilie Perez approach the matter of identity, of the Roman remains within a so-called barbarian world and the mixture of migrants and minorities inside this "fluid" society. Once again, archaeology is a means to an end, bringing information regarding the status and identity in the Merovingian world and also the polarization of gender and the place of children, as reflected by their burial graves.

The flourishing of the Merovingian world into a society becomes visible through the studies offered in Part III by Yitzhak Hen, Edward James, Laury Sarti, Gregory Halfond, Peregrinde Horden and Albrecht Diem. It becomes clear that the once-considered barbarians developed into a social network of courts and courtiers, and established both a male and female elite. All strata of their society were influenced and organized, from the military to the ecclesiastic structures, to matters of public health, hospitals and charity to adopting and developing their very own Merovingian monasticism.

As it is shown by history, each stable power structure follows a path to "success" and comes to a point where it needs to push its boundaries, be they visible or invisible. In Part IV, Stefan Esedres, Robin Fleming, JeanMichel Picard, Ralph W. Mathisen, Matthias Hardt and Jonathan J. Arnold turn the attention to the diplomatic and military endeavors of Merovingian authority, towards Byzantium or to other power of structures, the Irish, the Avars, the Slavs, Ostrogoths and Lombards, thus linking them to all key political and military players of their time. This can only mean that the Merovingians were seen as a power to be taken into account, to be feared, revered or fought against.

Their written culture is the subject of studies in Part V, researched by Helmut Reimitz, Alice Rio, Kamie Kreiner, Andrew Gillett and Mark A. Handley, dealing with matters of history of historiography, legal Merovingian tradition, their hagiography, epigraphy, as well as written proofs of communication networks.

In Part VI, their landscapes are turned into the subject of analysis by S.T. Loseby, Luc Bourgeois, Alexandra Chavarria Arnau, Pascale Chevalier, Edith Petremann, Paolo Squatriti, and Jean-Hervé Yvinec together with Maude Barme. Their essays focus on the role of urban Merovingian settlements and the way they manage to form an urban network, as well as on the faith of rural communities after the fall of the Roman Empire, the Merovingian religious architecture. Two aspects of Merovingian landscapes 
that depict more recent historiographical interest are included in this volume, dedicated to crop regime and medieval diet in northern Gaul.

In Part VII, the economy of the Merovingians is the leitmotif of studies written by Dries Tys, Jürgen Strothmann, Constantin Pion et alii., Michel Bonifay and Dominique Pieri, Frans Theuws, and Ralph J. Patrello. The trade of bead and garnet, of ceramics and the "movement" of coinage through maritime and river trades, between the Merovingian and the Mediterranean or Indian worlds, are case studies that are explored within this chapter. Longdistance trade towards the rural population of Northern Gauls, as well as an analysis of burial graves' inventory in Southern Gaul, are also part of it.

The final studies, in Part VIII, are dedicated to the supernatural and the afterlife and are the result of research undertaken by Genevra Kornbluth, William E. Klingshirn, Isabel Moreira, Els Rose, Lisa Kaaren Bailey and Lynda Coon, depicting both pagan and Christian features of the Merovingian world.

When finishing the Handbook the reader can only revere its authors for their sturdy endeavor, for it is through this volume that readers and further generations can immerse into a world considered, up until now, a barbarian one. 